\title{
Clinical and molecular analysis of nine families with Adams-Oliver syndrome
}

\author{
Pieter Verdyck ${ }^{1}$, Muriel Holder-Espinasse ${ }^{2}$, Wim Van $\mathrm{Hul}^{1}$ and Wim Wuyts ${ }^{*, 1}$ \\ ${ }^{1}$ Department of Medical Genetics, University of Antwerp, Antwerp, Belgium; ${ }^{2}$ Department of Clinical and Molecular \\ Genetics, Institute of Child Health, London, UK
}

Adams-Oliver syndrome (AOS) is defined by the combination of limb abnormalities and scalp defects, often accompanied by skull ossification defects. We studied nine families affected with AOS, eight of which have not been clinically described before. In our patients, scalp abnormalities were most often found, followed by limb and skull defects. The most common limb abnormalities appeared to be brachydactyly, syndactyly of toes 2 and 3 and hypoplastic toenails. Additional features observed were cutis marmorata telangiectatica congenita, cryptorchidism and cardiac abnormalities. In an attempt to identify the diseasecausing mutations in our families, we selected two genes, ALX4 and MSX2, which were considered serious candidates based on their known function in skull and limb development. Mutation analysis of both genes, performed by direct sequencing, identified several polymorphisms, but no disease-causing mutations. Therefore, we can conclude that the AOS in our set of patients is not caused by mutations in ALX4 or MSX2. European Journal of Human Genetics (2003) 11, 457-463. doi:10.1038/sj.ejhg.5200980

Keywords: Adams-Oliver syndrome; MSX2; ALX4; mutation analysis

\section{Introduction}

Adams-Oliver Syndrome (AOS) is characterized by the combined occurrence of aplasia cutis congenita (ACC) and transverse limb abnormalities. The former are scalp lesions most frequently found on the vertex of the skull that are variable in depth as well as in size. ${ }^{1,2}$ Often, skull defects underlying the scalp lesions are found. The most frequently observed limb malformations in this disorder include syndactyly (bony/cutaneous), brachydactyly, polydactyly, oligodactyly and hypoplastic finger/toenails. ${ }^{3}$ There is, however, a great variability in severity ranging from the complete absence of the foot or hand to only mild manifestations or normal appearance, as seen in obligate AOS carriers. ${ }^{2}$ AOS is mostly inherited as an autosomal dominant trait but also a suggestive autosomal recessive mode of inheritance has been described. ${ }^{4-7}$

*Correspondence: Dr W Wuyts, Department of Medical Genetics, University of Antwerp, Universiteitsplein 1, 2610 Wilrijk, Belgium. Tel: +32-3-820.26.77; fax: +32-3-820-25-66; wwuyts@uia.ua.ac.be Received 2 October 2002; revised 24 January 2003; accepted 5 February 2003
Several genes implicated in skull and limb development have already been identified and animal models in which these genes are knocked out or overexpressed have been generated to gain more insight in their exact function and regulation. Two genes, $A L X 4$ and MSX2, have previously been shown to be crucial for proper skull and limb development. Both are homeobox transcription factors and inactivating mutations in either gene results in foramina parietalia permagna (FPP).$^{8-11}$ This is a relatively rare disorder characterized by ossification defects in the parietal bones resulting in (large) foramina, which can persist in the calvaria far beyond childhood. ${ }^{12-14}$ An activating MSX2 mutation on the other hand is known to be responsible for the Boston type craniosynostosis. ${ }^{15}$

Mouse models have been generated for both transcription factors further supporting their important role in skull and limb development. ${ }^{16,17}$ The functional importance of the ALX4 and MSX2 genes in these processes and similarities between the AOS phenotype and the KO mouse models for these genes, make both genes strong candidates for this disorder. To evaluate the role of these genes in the pathogenesis of AOS, we performed molecular analysis of MSX2 and ALX4 in our set of families with AOS. 


\section{Patients, materials and methods}

\section{Patients}

Nine AOS families were included in this study (Figure 1). Family 1 originates from Canada, while family 9 is a Northern American family that has previously been described. ${ }^{18}$ The remaining seven families come from the
United Kingdom. Diagnosis of the patients was made after detailed examination of hands, feet and skull.

\section{Mutation analysis}

Mutation analysis of $A L X 4^{10}$ and $M S X 2^{9}$ was performed using primers previously described. For amplifications of
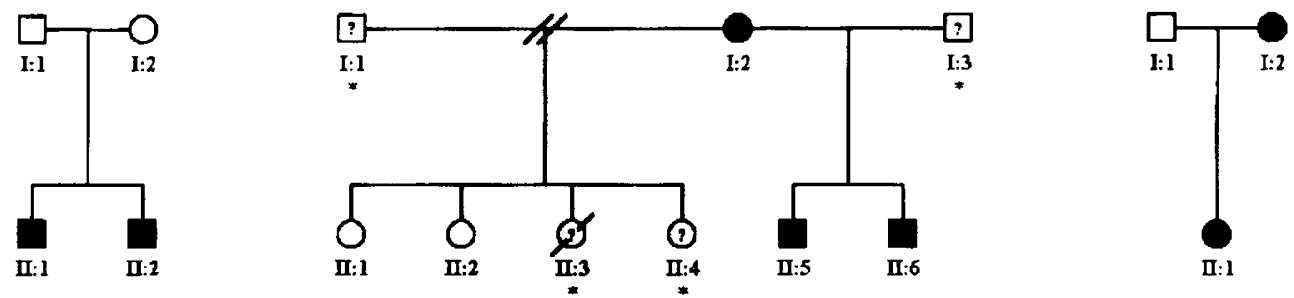

Farndy 4

Farnity 5
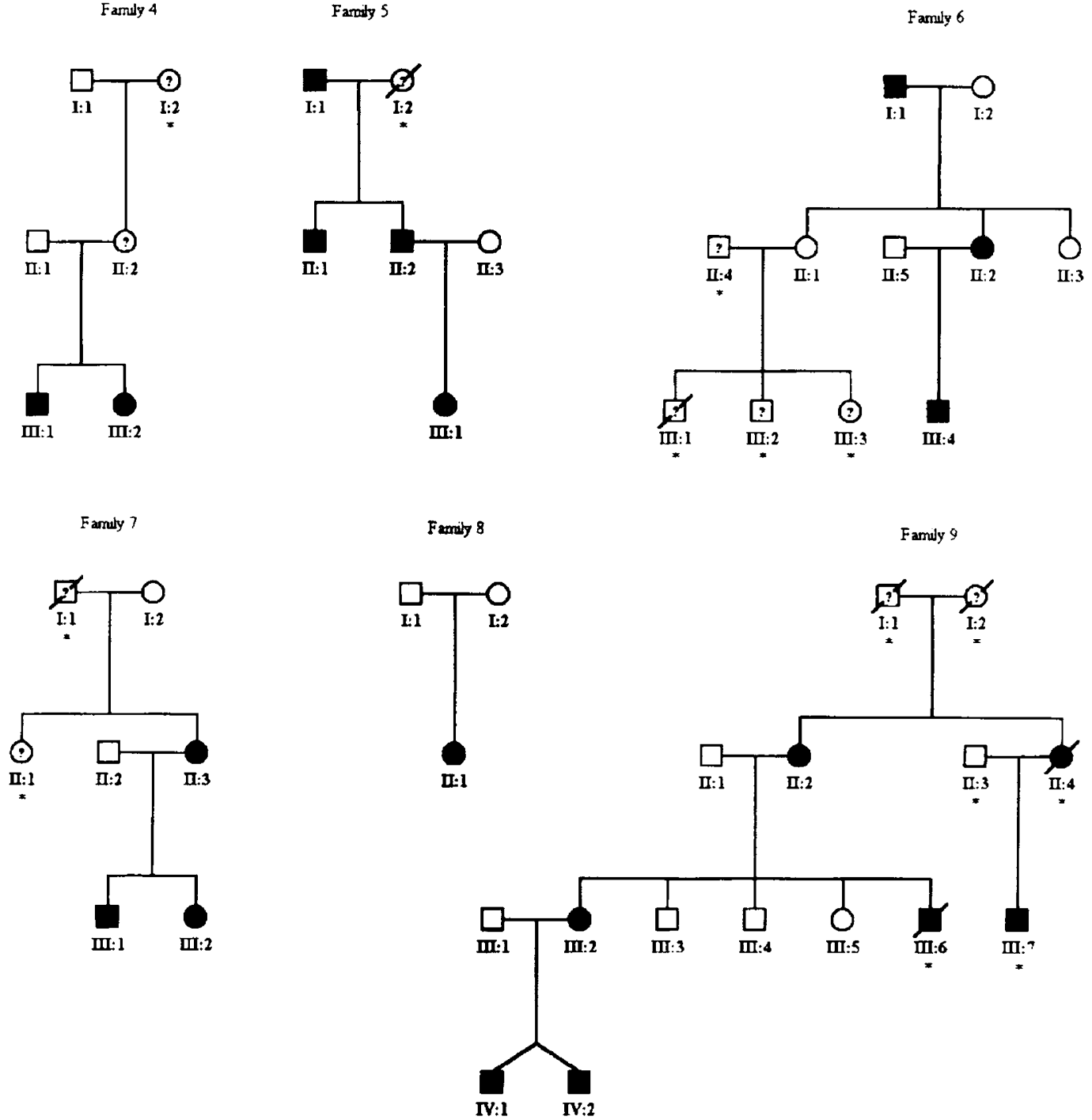

Figure 1 Pedigrees of the nine AOS families. * indicates that no DNA was available for study. Unknown disease status is indicated by a '?'. 
ALX4 exons, 35 cycles were executed at an annealing temperature of $65^{\circ} \mathrm{C}$, except for exon 2, which was amplified at $60^{\circ} \mathrm{C}$. PCR-enhancer system (Invitrogen) with $1 \times$ enhancer solution was used to obtain optimal amplification. The coding region and intron exon boundaries of MSX2 were amplified using an annealing temperature of $52^{\circ} \mathrm{C}$ during 35 cycles in $1 \times$ GC-melt solution (Clontech). All PCR products were purified with Concert rapid PCR purification system (Life Technologies) and sequenced using Big-Dye terminator chemistry (PerkinElmer) on an ABI 3100 automated sequencer.

In addition, linkage to the $A L X 4$ locus on chromosome 11p11 was analyzed with $A L X 4$ flanking markers D11S554 and D11S903 as described previously. ${ }^{19}$ MSX2 linkage was tested by analysis of the intragenic MSX2GT repeat reported previously. ${ }^{15}$ The PCR-amplification mixture contained dNTPs $(4 \times 10 \mathrm{mM})$. A volume of $0.5 \mathrm{pmol}$ of the two locus-specific primers and an IRD800-labeled M13reverse primer (5'-GGATAACAATTTCACACAGG-3'), $1 \times$ PCR buffer and Taq DNA polymerase. After a denaturation step of $5 \mathrm{~min}$ at $96^{\circ} \mathrm{C}, 35$ cycles of $1^{\prime}$ at $96^{\circ} \mathrm{C}, 45^{\prime \prime}$ at $57^{\circ} \mathrm{C}$ and $45^{\prime \prime}$ at $72^{\circ} \mathrm{C}$ a final elongation step at $72^{\circ} \mathrm{C}$ for $10 \mathrm{~min}$ was performed. Amplification products were analyzed on a LI-COR IRD800 detection system.

\section{Results}

Clinical analysis

Patients and relatives from nine families (Figure 1) with AOS were clinically investigated for the presence of scalp, skull and limb abnormalities. Results of this clinical analysis are summarized in Table 1.

Family 1 In this family, which originates from Canada, two boys (II-1 and II-2) with similar defects were born out of healthy parents. The boys both show major scalp and cranial defects (Figure 2a), brachydactyly and syndactyly of second and third toes. Patient II-2 also had tapering phalanges. Both parents showed no defects of scalp, skull or limbs.

Family 2 Clinical analysis of patient II-6 of this family revealed a combination of scalp, hand and foot defects. He

Table 1 Summary of clinical data of the affected members of the families

\begin{tabular}{|c|c|c|c|c|c|c|c|c|c|}
\hline Family & $I D$ & $\begin{array}{l}\text { Scalp } \\
\text { defect }\end{array}$ & $\begin{array}{l}\text { Skull } \\
\text { defect }\end{array}$ & $\begin{array}{l}\text { Brach } \\
\text { (hand) }\end{array}$ & $\begin{array}{l}\text { Abnormal } \\
\text { fingernails }\end{array}$ & $\begin{array}{l}\text { Syn } \\
\text { (toes) }\end{array}$ & $\begin{array}{l}\text { Brach } \\
\text { (toes) }\end{array}$ & $\begin{array}{l}\text { Abnormal } \\
\text { toenails }\end{array}$ & Other findings \\
\hline Family 1 & $\begin{array}{l}\mathrm{II}-1 \\
\mathrm{II}-2\end{array}$ & $\begin{array}{l}x \\
X\end{array}$ & $\begin{array}{l}x \\
x\end{array}$ & $\begin{array}{l}x \\
x\end{array}$ & & $\begin{array}{l}x \\
x\end{array}$ & $x$ & & \\
\hline Family 2 & $\begin{array}{l}\text { I-2 } \\
\text { II-5 } \\
\text { II-6 }\end{array}$ & $\begin{array}{l}x \\
x\end{array}$ & & $x$ & $x$ & $x$ & $x$ & $\begin{array}{l}x \\
x\end{array}$ & Bicuspid aortic valve \\
\hline Family 3 & $\begin{array}{l}\mathrm{I}-2 \\
\mathrm{II}-1\end{array}$ & $\begin{array}{l}x \\
x\end{array}$ & & & & $x$ & $x$ & $x$ & $\begin{array}{l}\text { Cutis marmorata } \\
\text { Cutis marmorata }\end{array}$ \\
\hline Family 4 & $\begin{array}{l}\text { III-1 } \\
\text { III-2 }\end{array}$ & $\begin{array}{l}x \\
x\end{array}$ & $x$ & & & & $x$ & $x$ & $\begin{array}{l}\text { Cryptorchidism and small penis } \\
\text { Severe developmental delay }\end{array}$ \\
\hline Family 5 & $\begin{array}{l}\text { I-1 } \\
\text { II-1 } \\
\text { II-2 } \\
\text { III-1 }\end{array}$ & $\begin{array}{l}? \\
\mathrm{X} \\
? \\
\mathrm{X}\end{array}$ & $\begin{array}{l}? \\
? \\
? \\
?\end{array}$ & $?$ & $?$ & $\begin{array}{l}\mathrm{X} \\
?\end{array}$ & $\begin{array}{l}\mathrm{X} \\
? \\
\mathrm{X} \\
\mathrm{X}\end{array}$ & $?$ & \\
\hline Family 6 & $\begin{array}{l}\text { I-1 } \\
\text { II-2 } \\
\text { III-4 }\end{array}$ & $\begin{array}{l}X \\
X \\
X\end{array}$ & $x$ & $\begin{array}{l}x \\
x\end{array}$ & $X$ & & $\begin{array}{l}x \\
x\end{array}$ & $x$ & $\begin{array}{l}\text { Symphalangism of toes } 2 / 3 / 4 \text {, } \\
\text { clinodactyly of fifth fingers } \\
\text { Epilepsy }\end{array}$ \\
\hline Family 7 & $\begin{array}{l}\text { II-3 } \\
\text { III-1 } \\
\text { III-2 }\end{array}$ & $\begin{array}{l}X \\
X \\
X\end{array}$ & & $x$ & & & $\begin{array}{l}x \\
x\end{array}$ & $x$ & Hallux valgus \\
\hline Family 8 & II-1 & $x$ & $x$ & & & & $x$ & $x$ & \\
\hline Family 9 & $\begin{array}{l}\text { II-2 } \\
\text { III-2 } \\
\text { IV-1 } \\
\text { IV-2 }\end{array}$ & $\begin{array}{l}? \\
X \\
X \\
X\end{array}$ & $x$ & $x$ & $?$ & $?$ & $?$ & $x$ & $\begin{array}{l}\text { Cardiovascular malformations }{ }^{a} \\
\text { Cardiovascular malformations }^{a}\end{array}$ \\
\hline
\end{tabular}

Question marks indicate that no data was available. $\mathrm{X}$ indicates presence of the clinical symptom. Brach:brachydactyly; Syn:syndactyly. ${ }^{\mathrm{L}}$ Lin et al. ${ }^{18}$ 

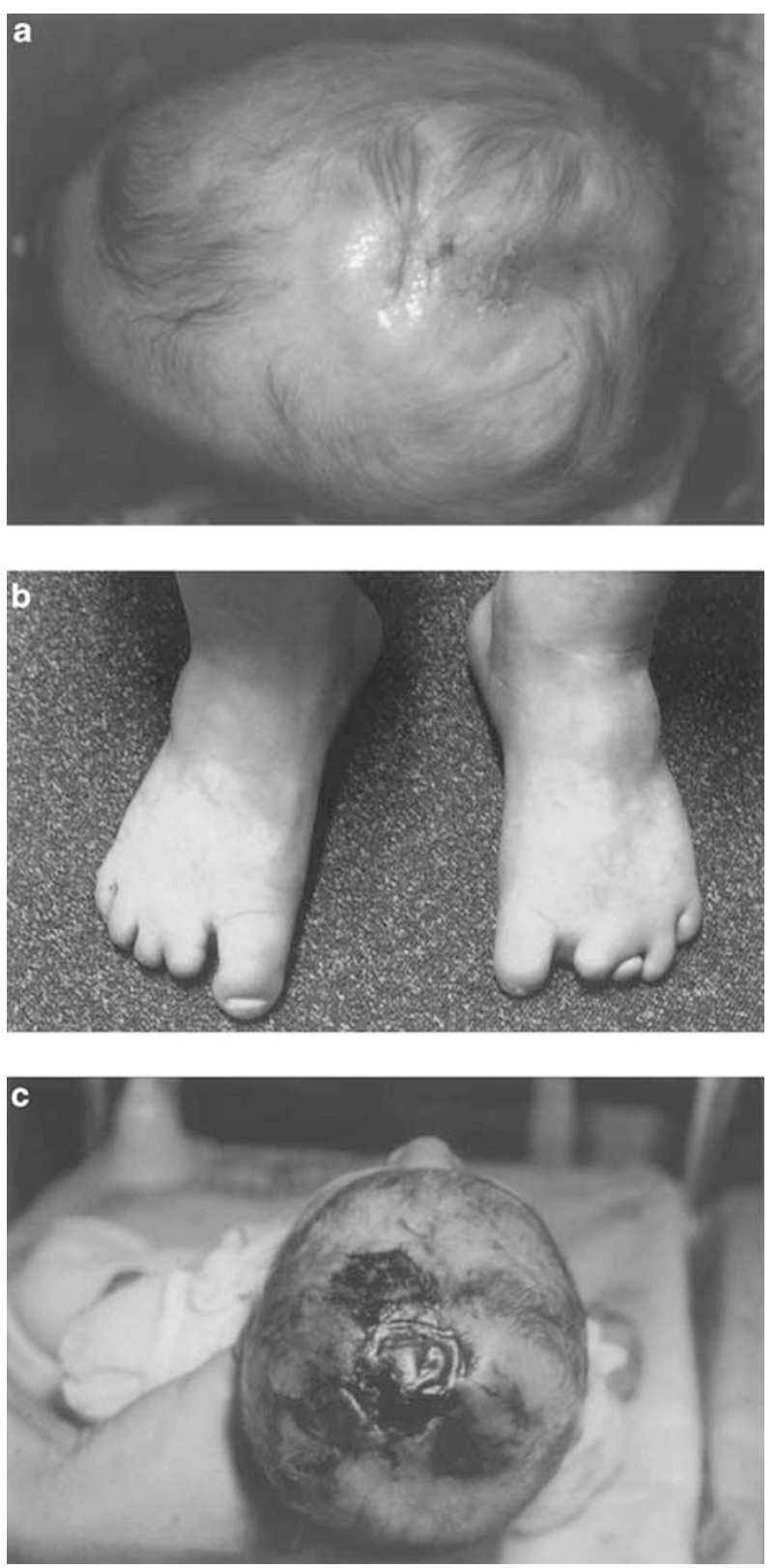

Figure 2 Characteristic features of Adams-Oliver syndrome present in our set of AOS patients. (a) Patient II2 (family 1) showing severe skull and scalp defects. (b) foot abnormalities including syndactyly, shortening of the digits and missing toenails in patient 116 (family 2) (c) scalp and underlying skull defect in patient III4 (family 6).

had a large scalp defect over the crown and short left fingers with small phalanges. His nails on the third and fourth fingers of the right hand were hypoplastic. The terminal phalanges of both feet were hypoplastic as well with missing toenails on toes 2,3,4 and 5 of the left foot and of toes 2 and 3 of the right. On the left foot, also syndactyly of toes $2 / 3$ was observed (Figure $2 b$ ). His brother
(II:5) also showed extensive ACC over the crown. In this patient, no hand or foot defects were observed, except for a hypoplastic second toenail on the right foot. Their mother showed $2 / 3$ syndactyly on both feet and a bicuspid aortic valve. Two other children of this woman from another marriage (II-1 and II-2) did not show any clinical features of AOS. The father of the affected children was not examined.

Family 3 In this English family, mother and daughter are affected. The mother shows a scalp defect and cutis marmorata teleangiectatica congenita. The daughter is more severely affected and also shows syndactyly and brachydactyly with absent nails on left toes 2,3 and 4 . The father was not affected.

Family 4 Two affected children, brother and sister, have been identified in this family. The girl (III-2) had a large scalp defect with extensive vascular damage and short toes without toenails. Apart from the typical symptoms of AOS, also severe developmental delay was observed. Her younger brother showed a persistent open anterior fontanel, a subdural hematoma and a bald streak over the sagittal suture. He also suffered from cryptorchidism and a small penis. The father and maternal grandfather showed no grand abnormalities. The patients mother had short toes.

Family 5 In this English family, three generations are affected, with male to male transmission of the disorder. The youngest member (III-1) suffers from ACC and has small toes. Her father (II-2) was diagnosed to have short 3,4 and 5 toes with short phalanges. His brother (II:1) also had a bald patch, similar to the ACC of his niece. The grandfather (I-1) shows syndactyly of second and third toes and short third and fourth toes.

Family 6 Family 6 comprises three patients in three generations. The proband (III:4) is severely affected with a large scalp defect, an underlying skull ossification defect (Figure 2c) and amputated toes. He had a short left index finger with a small nail. He also suffered from epilepsy. His mother had a milder phenotype, with a scalp defect and short fingers/toes with normal nails. The probands' maternal grandfather was also affected, with a scalp defect and a mild depression in the mid-line in the region of the fused coronal suture. He suffered from clinodactyly of the hands as well, and from bony syndactyly of the middle and distal phalanges of toes 3, 4 and 5. Furthermore, he had small middle phalanges of the second toes and small distal phalanges of the first (big) toes. The father, aunts and maternal grandmother were also examined but this revealed no abnormalities.

Family 7 Three patients, an affected mother (II:3) and her two affected (III:1, III:2) children, have been identified in this family. The boy was born with an open patch on his 
scalp, which healed two days later, with a large bald area remaining. He also has foot abnormalities with absent distal phalanges of the fifth toes and very small distal phalanges of the other toes with minute epiphyses. His younger sister showed a major scalp defect and hypoplastic phalanges of both hands and feet. The mother was more mildly affected, with an area of furrowing over the crown and bilateral hallux valgus.

Family 8 The only known patient of this family was born with a large scalp defect. Under this, a large bony defect was observed. She had shortened first toes (bilaterally) and no nails on toes 1 and 5. Clinical examination of her parents revealed no abnormalities.

Family 9 This family has been reported before as family 1 in Lin et al. ${ }^{18}$ DNA from four patients was studied. Typical scalp defects were observed in three of them, two twin boys and their mother. Hypoplasia of the fingertips and all nails was observed in one of the twin boys. In addition, all these patients and the maternal grandmother showed cardiovascular malformations. DNA from three apparently unaffected sibs of the mother was also available.

\section{Molecular analysis of $A L X 4$}

To analyze the $A L X 4$ gene, we sequenced all four exons including the intron-exon boundaries. Four sequence variations were found (Table 2). A 63C $>\mathrm{T}$ change in exon 1 was detected in patient III-2 of family 4 . This substitution at the third position in the tyrosine codon causes no amino-acid change (TAC $\rightarrow$ TAT) at the protein level and was not detected in 100 control chromosomes. The second sequence variance, a 104C > G transversion, was found in several individuals of families $1,2,3,4,5$ and 9. At the amino-acid level this results in the substitution of an arginine (AGG) for a threonine (ACG). This substitution was also frequently found in a control population of 100 chromosomes with $47 \%$ possessing the $\mathrm{C}$-allele and $53 \%$ having the G-allele. A third polymorphism in exon $1,304 \mathrm{C}>\mathrm{T}$, was identified in families $1,2,3,4,5$ and 9 . It causes a change from serine into proline at amino-acid position 102. Analysis of 100 control chromosomes revealed an allele frequency of $37 \%$ for the $\mathrm{G}$ allele and $63 \%$ for the $\mathrm{C}$ allele. The fourth polymorphism, 1074C $>\mathrm{T}$ (His358His) is located in exon 4 . This silent mutation was detected in families $1,3,7$ and 9 , but it is also frequent in the control population with $71 \%$ possessing the $\mathrm{C}$-allele, and $29 \%$ possessing the T-allele.

Analysis of ALX4 flanking markers D11S903 and D11S554in all families (excluding families 3 and 8, which were too small), further revealed that no recombination between these two flanking markers and AOS could be observed in families 1, 2, 6 and 9. However, in the latter family, the unaffected individual III- 4 inherited the same
Table 2 Polymorphisms found in the ALX4 and MSX2 genes

Exon

Frequency in controls (\%)

ALX4

$63 \mathrm{C} \rightarrow \mathrm{T}(\mathrm{Y} 21 \mathrm{Y})$

$104 \mathrm{C} \rightarrow \mathrm{G}(\mathrm{T} 35 \mathrm{R})$

$304 \mathrm{~T} \rightarrow \mathrm{C}(\mathrm{S} 102 \mathrm{P})$

$1074 \mathrm{C} \rightarrow \mathrm{T}(\mathrm{H} 158 \mathrm{H})$

$1-100 / 0$

$1 \quad 63 / 37$

$M S \times 2$

$386 \mathrm{C} \rightarrow \mathrm{T}(\mathrm{T} 129 \mathrm{M})$

2

$90 / 10$

D11S903/D11S554 alleles from his affected mother as his affected sister. A recombination was observed with at least one of these two markers in the remaining families.

\section{Molecular analysis of MSX2}

To analyze the MSX2 gene, both exons were sequenced using intronic primers. One polymorphism, $386 \mathrm{C}>\mathrm{T}$ located in the beginning of exon 2, was found heterozygously in members of families 5 (II-1) and 6 (III-4) and causes an amino-acid substitution of threonine for methionine. Allele frequencies were determined at 0.10 for the Tallele and 0.90 for the $\mathrm{C}$-allele in the control population (Table 2). No further molecular abnormalities were detected.

Analysis of the intragenic MSX2 CA repeat revealed recombination with AOS in families 4 and 5. In family 9, healthy individual III-4 again inherited the same MSX2CA allele from his affected mother as his affected sister. The remaining families were not informative for this marker.

\section{Discussion}

We describe here nine AOS families with 27 affected individuals, 24 of whose detailed clinical data were available (Table 1). Consistent with previous reports, $3,20,21$ we also observed a great intrafamilial clinical variability that is characteristic for AOS. A total of 20 patients were diagnosed having scalp defects and eight also had underlying skull defects. Limb abnormalities were also very frequent with seven of the patients having hand abnormalities and seventeen having abnormalities of one or both feet. In the limb abnormalities brachydactyly, syndactyly of toes 2 and 3 and hypoplastic toe/fingernails were most common. In all families at least one patient is found with both scalp defect and limb abnormalities, the main characteristic features of AOS.

Apart from skull, scalp and limb defects, several additional features were observed in some of our AOS patients. In family 3 , cutis marmorata telangiectatica congenita was found in both patients. This symptom has frequently been 
found in $\mathrm{AO}$ patients and suggests a mechanism of early embryonic vascular disruption as one of the underlying causes of this syndrome. ${ }^{20,22-29}$

Various intracranial abnormalities have been described in AOS patients. They include encephalocele, ${ }^{2}$ microcephaly, $^{21}$ hypoplasia of the left arteria cerebri media and right spastic hemiplegia 27 and dysplasia of the cerebral cortex. ${ }^{30}$ As a consequence, secondary symptoms, such as epilepsy are frequently found in AOS patients. One severely affected patient in our study (III-4, family 6) was also reported to be epileptic, but unfortunately no CT scans were available to gain information about possible causative structural brain abnormalities in this patient.

In a previous study which included family 9 , Lin et al ${ }^{18}$ estimated the occurrence of cardiovascular malformation in AOS patients to be about $20 \%$. In our remaining eight families, one case of biscupid valve (patient I2, family 2) was noted. However, this may be an underpresentation as not all patients had extensively been screened for cardiovascular abnormalities.

In the literature both autosomal dominant and recessive modes of inheritance have been described for AOS. ${ }^{4-7}$ Six of the families described here show clear autosomal dominant segregation with male-to-male transmission in family 5 , excluding an X-linked pattern of inheritance. The remaining families $(1,4$ and 8$)$ are too small to be conclusive on this subject but we could not find any suggestion for a recessive form of AOS. Indeed, none of the families were consanguineous and in family 1 an autosomal dominant mode of inheritance was suspected with an anamnestic positive history of undefined 'skin-defects' in a maternal relative. Therefore, the segregation pattern in these small families can perfectly be explained by reduced penetrance or 'de novo' mutations that have arisen.

With the genetic cause underlying AOS being unknown, we selected several candidate genes implicated in craniofacial and limb development in order to identify the AOS gene. Two of these candidate genes, encoding the transcription factors ALX4 and MSX2, were analyzed in the 9 AOS families. Haploinsufficiency of ALX4 is already known to be related to FPP, a disorder characterized by round-to-oval skull ossification defects on the vertex of the skull. Alx4 is expressed in cells of the craniofacial and limb bud mesenchyme. In the limb bud it is expressed only anteriorly, where it suppresses the formation of a zone of polarizing activity (ZPA) and so confines it to the posterior part of the limb bud. In this way it helps to define the anterior-posterior axis. In Alx4 knockout mice, an ectopic anterior ZPA is formed with preaxial polydactyly as a result. Apart from limb abnormalities, the knockout mice show also a decreased size of the parietal skull bones. ${ }^{16}$ These similarities between Alx4 knockout and AOS phenotype prompted us to analyze this gene in our AOS families.
We used direct sequencing to investigate the $A L X 4$ gene in the nine families. In this way, four sequence variations were found. Variations $104 \mathrm{C}>\mathrm{G}, 304 \mathrm{C}>\mathrm{T}$ and $1074 \mathrm{C}>\mathrm{T}$ are commonly found in the control population and thus can be regarded as polymorphisms. Variation $63 \mathrm{C}>\mathrm{T}$ was not found in 100 control chromosomes, but does not result in an amino-acid substitution and does not segregate with the disease in the family 4 since it only was found in one of two affected siblings. In addition to the mutation analysis, we analyzed $A L X 4$ flanking markers to see whether we could further exclude the $A L X 4$ gene. Although most of the families were too small to obtain fully conclusive results, recombination with at least one of the analyzed markers was observed in families 4, 5 and 7. As these markers are located approximately $1 \mathrm{cM}$ on each side of the $A L X 4$ gene this further suggests that $A L X 4$ does not cause AOS in these families. In the largest family (family 9) all patients from which DNA was available and one of the not affected individuals showed a common haplotype for D11S903/ D11S554. However, due to the reduced penetrance of AOS linkage to $A L X 4$ can not be excluded. It would be interesting however, to genotype the remaining patients from which no DNA was available to us, to obtain a definite conclusion for this family.

MSX2 is another strong candidate since it is expressed in many sites of epithelial and mesenchymal interactions, including the calvaria and the limb bud, the tissues affected in AOS patients. In the limb bud, Ms 2 is specifically expressed in parts of the mesenchym and in the apical ectodermal ridge, one of the three signaling centers of the hand and thought to regulate the proximodistal axis. In Msx2-knock-mice animals, limb abnormalities include reduced appendicular skeletal lengths, with femur and tibia lengths 83 and $88 \%$ that of wild-type animals. The calvaria of $M s \times 2$ knockout mice show many abnormalities of which a large mid-line foramen and small abnormally shaped interparietal, and supraoccipital bones are the most striking. ${ }^{17}$ In humans, gain of function mutations in MSX2 cause Boston-type craniosynostosis, ${ }^{15}$ in which the cranial sutures fuse prematurely (and in which sometimes hand abnormalities are seen). Loss of function can lead to FPP, considered as an opposite effect. Interestingly, a possible association between MSX2 mutations and ACC (a feature of AOS) has already been described in two patients with both ACC and FPP where a MSX2- mutation has been identified. 9,31 To examine this gene, we performed sequence analysis in the collected families. However, no mutation was found, only one polymorphism. Linkage analysis did not provide any further suggestion for linkage to the MSX2 locus with even exclusion of MSX2 in at least two families and again a recombination event in an unaffected individual in family 9. Therefore, we conclude that there are no indications for MSX2 involvement in the pathogenesis of autosomal dominant AOS. 
In general, we did not find any indications for involvement of $A L X 4$ or MSX2 in the pathogenesis of autosomal dominant AOS. Further studies have to be performed to identify the responsible gene(s) in AOS.

\section{Acknowledgements}

This study was supported by a NOI BOF UA grant to WW. We are grateful to Dr W Reardon and Dr R Winter for collecting DNA and providing clinical information of the AOS families.

\section{References}

1 Adams FH, Oliver CP: Hereditary deformities in man due to arrested development. J Hered 1945; 36: 3-7.

2 Kuster W, Lenz W, Kaariainen H, and Majewski F: Congenital scalp defects with distal limb anomalies (Adams-Oliver syndrome): report of ten cases and review of the literature. $\mathrm{Am} \mathrm{J}$ Med Genet 1988; 31: 99-115.

3 Sybert VP: Aplasia cutis congenita: a report of 12 new families and review of the literature. Pediatr Dermatol 1985; 3: 1-14.

4 Koiffmann CP, Wajntal A, Huyke BJ, Castro RM: Congenital scalp skull defects with distal limb anomalies (Adams-Oliver syndrome-McKusick 10030): further suggestion of autosomal recessive inheritance. Am J Med Genet 1988; 29: 263-268.

5 Sybert VP: Congenital scalp defects with distal limb anomalies (Adams-Oliver syndrome-McKusick 10030): further suggestion of autosomal recessive inheritance. Am J Med Genet 1989; 32: 266-267.

6 Tekin M, Bodurtha J, Ciftci E, Arsan S: Further family with possible autosomal recessive inheritance of Adams-Oliver syndrome. Am J Med Genet 1999; 86: 90-91.

7 Unay B, Sarici SU, Gul D, Akin R, Gokcay E: Adams-Oliver syndrome: further evidence for autosomal recessive inheritance. Clin Dysmorphol 2001; 10: 223-225.

8 Wilkie AO, Tang Z, Elanko N et al. Functional haploinsufficiency of the human homeobox gene MSX2 causes defects in skull ossification. Nat Genet 2000; 24: 387-390.

9 Wuyts W, Reardon W, Preis S et al. Identification of mutations in the MSX2 homeobox gene in families affected with foramina parietalia permagna. Hum Mol Genet 2000; 9: 1251-1255.

10 Wuyts W, Cleiren E, Homfray T, Rasore-Quartino A, Vanhoenacker F, Van HW: The ALX4 homeobox gene is mutated in patients with ossification defects of the skull (foramina parietalia permagna, OMIM 168500). J Med Genet 2000; 37: 916-920.

11 Mavrogiannis LA, Antonopoulou I, Baxova A et al. Haploinsufficiency of the human homeobox gene ALX4 causes skull ossification defects. Nat Genet 2001; 27: 17-18.

12 Schmidt-Wittkamp E, Christians H: Lacunar changes in the parietal bones. Observations on 75 members of a family with an increased occurrece of parietal foramia. Fortschr Geb Rontgenstr Nuklearmed 1970; 113: 29-38.

13 Zabek M: Familial incidence of foramina parietalia permagna. Neurochirurgia (Stuttg) 1987; 30: 25-27.
14 Little BB, Knoll KA, Klein VR, Heller KB: Hereditary cranium bifidum and symmetric parietal foramina are the same entity. Am J Med Genet 1990; 35: 453-458.

15 Jabs EW, Muller U, Li X et al. A mutation in the homeodomain of the human MSX2 gene in a family affected with autosomal dominant craniosynostosis. Cell 1993; 75: 443-450.

$16 \mathrm{Qu} \mathrm{S}$, Niswender KD, Ji Q et al. Polydactyly and ectopic ZPA formation in Alx-4 mutant mice. Development 1997; 124: 3999-4008.

17 Satokata I, Ma L, Ohshima $\mathrm{H}$ et al. Msx2 deficiency in mice causes pleiotropic defects in bone growth and ectodermal organ formation. Nat Genet 2000; 24: 391-395.

18 Lin AE, Westgate MN, van der Velde ME, Lacro RV, Holmes LB: Adams-Oliver syndrome associated with cardiovascular malformations. Clin Dysmorphol 1998; 7: 235-241.

19 Wuyts W, Van HW, Wauters J et al. Positional cloning of a gene involved in hereditary multiple exostoses. Hum Mol Genet 1996; 5: $1547-1557$

20 Whitley CB, Gorlin RJ: Adams-Oliver syndrome revisited. Am J Med Genet 1991; 40: 319-326.

21 Bamforth JS, Kaurah P, Byrne J, Ferreira P: Adams-Oliver syndrome: a family with extreme variability in clinical expression. Am J Med Genet 1994; 49: 393-396.

22 Hoyme HE, Jones KL, Van AM, Saunders BS, Benirschke K: Vascular pathogenesis of transverse limb reduction defects. $J$ Pediatr 1982; 101: 839-843.

23 Kuster W: Limb defects with cutis marmorata teleangiectatica congenita: Adams-Oliver syndrome. Acta Paediatr Scand 1989; 78: 627-628.

24 Bork K, Pfeifle J: Multifocal aplasia cutis congenita, distal limb hemimelia, and cutis marmorata telangiectatica in a patient with Adams-Oliver syndrome. $\mathrm{Br}$ I Dermatol 1992; 127: 160-163.

25 Frank RA, Frosch PJ: Adams-Oliver syndrome: cutis marmorata teleangiectatica congenita with multiple anomalies. Dermatology 1993; 187: 205-208.

26 Dyall-Smith D, Ramsden A, Laurie S: Adams-Oliver syndrome: aplasia cutis congenita, terminal transverse limb defects and cutis marmorata telangiectatica congenita. Australas J Dermatol 1994; 35: 19-22.

27 Fryns JP, Legius E, Demaerel P, van den Berghe H: Congenital scalp defect, distal limb reduction anomalies, right spastic hemiplegia and hypoplasia of the left arteria cerebri media. Further evidence that interruption of early embryonic blood supply may result in Adams-Oliver (plus) syndrome. Clin Genet 1996; 50: 505-509.

28 Swartz EN, Sanatani S, Sandor GG, Schreiber RA: Vascular abnormalities in Adams-Oliver syndrome: cause or effect? Am Med Genet 1999; 82: 49-52.

29 Keymolen K, De S, Bracke P, Fryns JP: The concurrence of ring constrictions in Adams-Oliver syndrome: additional evidence for vascular disruption as common pathogenetic mechanism. Genet Couns 1999; 10: 295-300.

30 Savarirayan R, Thompson EM, Abbott KJ, Moore MH: Cerebral cortical dysplasia and digital constriction rings in Adams-Oliver syndrome. Am J Med Genet 1999; 86: 15-19.

31 Preis S, Engelbrecht V, Lenard HG: Aplasia cutis congenita and enlarged parietal foramina (Catlin marks) in a family. Acta Paediatr 1995; 84: 701-702. 